\title{
Correction to: Real Estate Investment Trusts and Joint Ventures
}

\section{J. Eibel, Real Estate Investment Trusts and Joint Ventures, Essays in Real Estate Research 19, https://doi.org/10.1007/978-3-658-31977-9}

Chap. 4, p. 99: Please note the changed footnote text, FN 95: This Section is co-authored by Prof. Jan Mutl, PhD and Dr. Holger Markmann and is intended for separate publication.

Chap. 5, p. 121: Please note the changed footnote text, FN 108: This Section is co-authored by Prof. Jan Mutl, PhD and Dr. Holger Markmann and is intended for separate publication.

Both the correction has been updated in the book.

The updated version of these chapters can be found at https://doi.org/10.1007/978-3-658-27671-3_4 https://doi.org/10.1007/978-3-658-27671-3_5 